\title{
Publisher's Note: Reversible electron beam heating for suppression of microbunching instabilities at free-electron lasers [Phys. Rev. ST Accel. Beams 15, 022802 (2012)]
}

\section{Christopher Behrens, Zhirong Huang, and Dao Xiang}

(Received 14 June 2012; published 19 June 2012)

DOI: $10.1103 /$ PhysRevSTAB.15.069903

PACS numbers: 29.27.- a, 41.60.Cr, 41.85.Ct, 99.10.Fg

This paper was published online on 6 February 2012 with an omission of an author address footnote. The email address of the first author has been added online as of 15 June 2012.

Published by the American Physical Society under the terms of the Creative Commons Attribution 3.0 License. Further distribution of this work must maintain attribution to the author(s) and the published article's title, journal citation, and DOI. 